\title{
Fermentation characteristics and nutritive value of baled grass silages made from meadow fescue, tall fescue, or an orchardgrass cultivar exhibiting a unique nonflowering growth response
}

\author{
W. K. Coblentz, ${ }^{1 *} \odot$ M. S. Akins, ${ }^{2} \oplus$ and J. S. Cavadini ${ }^{3}$ \\ ${ }^{1}$ US Dairy Forage Research Center, USDA-Agricultural Research Service, Marshfield, WI 54449 \\ ${ }^{2}$ Department of Dairy Science, University of Wisconsin, Madison 53706 \\ ${ }^{3}$ Marshfield Agricultural Research Station, University of Wisconsin, Stratford 54484
}

\begin{abstract}
Throughout central Wisconsin, many soils are poorly drained, and perennial cool-season grasses are often planted as monocultures or in mixed stands with alfalfa because of the poor persistence of alfalfa under these growing conditions. Our objectives were to compare the fermentation characteristics and nutritive value of perennial cool-season grasses \{meadow fescue [Schedonorus pratensis (Huds.) P. Beauv.], orchardgrass (Dactylis glomerata L.), and endophyte-free tall fescue [Schedonorus phoenix (Scop.) Holub]\} conserved as baled silages with or without particle-size reduction, and at 2 moisture concentrations. Twenty-four plots (0.23 ha) were arranged in a randomized complete block design with 6 plots/block. Within each of the 4 field blocks, one of the 6 plots was assigned randomly to each of the $(3 \times 2)$ factorial combinations of forage type and bale cutting engagement (cut or uncut). The baler cutting mechanism consisted of 15 cutting knives, thereby creating a theoretical length of cut of about $8.1 \mathrm{~cm}$. Generally, sufficient forage was available to produce 2 bales/plot; therefore, one bale was packaged at relatively high moisture $(58.3 \%)$, whereas the other bale was made at an ideal moisture $(44.9 \%)$ for this silage preservation method. Theoretically, bale cutting can increase bale weights and densities by reducing particle size, thereby allowing inclusion of additional forage within the same-sized bale. In this experiment, bale-cutting within $1.2 \times 1.2 \mathrm{~m}$ silage bales $(\mathrm{n}=47)$ increased initial wet and dry bale weights by 4.1 and $4.7 \%$, respectively, but had no practical effect on measures of nutritive value, either on a pre- or postensiled basis. Cutter engagement tended to increase total volatile fatty acids in silages, thereby resulting in a $\mathrm{pH}$
\end{abstract}

Received August 2, 2019.

Accepted November 27, 2019.

*Corresponding author: wayne.coblentz@ars.usda.gov reduction of $0.07 \mathrm{pH}$ units (5.54 vs. 5.61). A unique nonflowering growth response by the first-cutting orchardgrass forage resulted in yields of dry matter for orchardgrass $(2,977 \mathrm{~kg}$ of dry matter/ha) that were only 52 to $53 \%$ of those observed for meadow $(5,580$ $\mathrm{kg}$ of dry matter/ha) or tall fescue $(5,763 \mathrm{~kg}$ of dry matter/ha), which did not differ. Despite the unique vegetative nature of orchardgrass, concentrations of neutral detergent fiber, acid detergent fiber, and acid detergent lignin determined before ensiling exhibited limited variability across forages (60.9 to $62.7 \%, 35.2$ to $36.4 \%$, and 2.75 to $2.99 \%$, respectively). However, a 30-h in vitro incubation determined that orchardgrass exhibited greater neutral detergent fiber digestibility (56.2\%) compared with meadow $(44.9 \%)$ or tall fescue (40.8\%), which were also statistically distinct.

Key words: baled silage, meadow fescue, orchardgrass, particle-length reduction, tall fescue

\section{INTRODUCTION}

The production of baled silages continues to be a popular form of forage conservation, particularly for small and mid-sized dairy and beef producers. Although most principles of good silage management are similar between baled and precision-chopped silages, some characteristics are notably different. One significant difference between the silage types is the general recommendation for moisture concentrations, which are drier for baled silages (45 to 55\%; Shinners, 2003). Recommendations for chopped silages, such as alfalfa (Medicago sativa L., $<70 \%$; Muck et al., 2003), or those summarized for bunker (65 to $75 \%$ ) or stave silos (60 to $70 \%$ ) are considerably wetter (Holland and Kezar, 1990; Mahanna and Chase, 2003). In part, this wide discrepancy results generally from the better performance of balers with drier forages, which seems logical because they are at least co-equally designed to package dry hay. A major consequence of ensiling drier, baled silages is the restriction of fermentation; several stud- 
ies in which baled alfalfa or alfalfa/grass forages were ensiled have reported very low concentrations of lactic acid $(\leq 0.58 \%)$ when the forage moisture concentration was $<45 \%$ at baling (Shinners et al., 2009; Coblentz et al., 2014, 2016b).

The unpredictability of the weather and wilting conditions, coupled with the improved capability of newer balers to handle wetter forages, may encourage some producers to bale forages at moisture concentrations greater than those suggested by Shinners (2003) to avoid rain damage to valuable silage crops. Several studies have reported concentrations of butyric acid approaching $1 \%$ of DM in grass and alfalfa forages baled at $\geq 74 \%$ and $60 \%$, respectively (Keles et al., 2009; Coblentz et al., 2016a), which exceeds the recommended target of $<0.1 \%$ for stable silages suggested by Mahanna and Chase (2003). Low forage moisture concentrations have an inhibitory effect on clostridial activity (Leibensperger and Pitt, 1987); as such, most potential problems with secondary clostridial activity can be eliminated by adhering to the 45 to $55 \%$ moisture recommendations suggested by Shinners (2003). The long-stem nature of most baled silages is also known to limit the rate and extent of fermentation by restricting the availability of plant sugars to lactic-acid-producing bacteria adhered to the plant surface (Nicholson et al., 1991; Muck et al., 2003; Savoie and Jofriet, 2003), and this characteristic of baled silages potentially increases susceptibility to secondary clostridial activity within silage bales, which tend to be more heterogeneous than precision-chopped silages.

Currently, many new balers can be purchased with factory-installed cutting mechanisms that are designed to reduce the particle length of forages as they are packaged into the bale. Mostly, these bale-cutting systems improve ease-of-mixing when (cut) baled silages are blended into TMR diets, but also could aid the release of sugars for silage fermentation. Some studies (Shinners, 2003; Borreani and Tabacco, 2006; Coblentz and Akins, 2019) have suggested that bale density is improved by particle-size reduction, but mostly these improvements have been relatively small, especially when calculated for alfalfa on a DM density basis $(\sim 4 \%$; Borreani and Tabacco, 2006). Similarly, Coblentz and Akins (2019) found bale-cutter engagement increased wet bale weights for alfalfa/grass forages by $4.2 \%$, but this response had no statistical effect on dry bale weights or DM density, although numerical advantages were observed for cut bales in both cases. Borreani and Tabacco (2006) reported little improvement in silage fermentation resulting from cutter engagement, whereas Coblentz and Akins (2019) noted a consistent 0.10 to 0.16 - $\mathrm{pH}$-unit reduction in the final $\mathrm{pH}$ of cut bales across a wide range of initial bale moistures. These responses suggest that engagement of bale-cutting mechanisms likely provides only marginal benefits to silage fermentation, and would be of little value as a managerial option for avoiding undesirable clostridial activity in silages exceeding the normal 45 to $55 \%$ moisture recommendation noted by Shinners (2003).

As noted, most past studies with bale-cutting mechanisms have evaluated alfalfa or alfalfa/grass mixtures, but have not considered monocultures of perennialgrass forages, which are typically easier to ensile because of their greater concentrations of water-soluble carbohydrates (WSC) and lower buffering capacities (BC; McDonald et al., 1991). Within that context, the effects of particle size reduction on the fermentation characteristics of perennial grass forages grown in the north-central United States are less clear generally, and specifically when forage moisture concentrations are relatively high $(>55 \%)$. Furthermore, it is also unclear whether particle-size reduction can provide any management insurance against undesirable clostridial activity when relatively wet grasses are preserved as baled silages. Our research objectives for this project were to compare the fermentation characteristics and nutritive value of cut and uncut perennial cool-season grass meadow fescue [Schedonorus pratensis (Huds.) P. Beauv.], orchardgrass (Dactylis glomerata L.), and endophyte-free tall fescue [Schedonorus phoenix (Scop.) Holub]\} silages baled at relatively high moisture concentrations $(58.3 \%)$, but also at an ideal moisture for baling (44.9\%; Shinners, 2003), to determine whether particle-size reduction can be used to improve the fermentation of baled grass silages.

\section{MATERIALS AND METHODS}

\section{Description of Field Site and Layout}

A 5.4-ha field site on the University of Wisconsin Marshfield Agricultural Research Station, located near Stratford, Wisconsin, was selected for this experiment. The site was subdivided on the basis of field topography and surface drainage into 4 field blocks, each consisting of an area 1.35 ha in size. Each field block had six 14.6 $\times 153.8 \mathrm{~m}$ plots; of these, 2 plots/block were assigned randomly to each of 3 perennial cool-season grasses (meadow fescue, orchardgrass, and endophyte-free tall fescue). As such, there were a total of 8 plots of each forage type within the 5.4-ha experimental layout. Each forage variety was obtained through Byron Seeds LLC (Rockville, IN) and included LiHerold meadow fescue, Echelon orchardgrass, and Kora endophyte-free tall fescue. All forage plots were established on July 25, 2017, 
and seeded at respective rates of 28,22 , and $28 \mathrm{~kg} / \mathrm{ha}$. Soil sampling to a $0.15-\mathrm{m}$ depth was conducted on November 7, 2017, and indicated (1) $\mathrm{pH}=7.01 \pm 0.055$; (2) $\mathrm{P}=46 \pm 3.2 \mathrm{mg} / \mathrm{kg} ;$ (3) $\mathrm{K}=181 \pm 10.5 \mathrm{mg} / \mathrm{kg}$; and (4) $\mathrm{OM}=3.5 \pm 0.15 \%$, where the standard deviation was based on variability among the 4 experimental blocks. No fertilizer of any type was applied before harvesting the forage for the research trial on June 29, 2018. For this research trial, 3 treatment factors and their interactions were evaluated; these included forage type, bale-cutter engagement, and moisture concentration. Within each field block, one of the 2 plots of each forage type was assigned randomly to have the bale cutter engaged (cut), and the other was designated to remain as long-stem forage (uncut). Furthermore, each plot was large enough to produce 2 bales, where one was designated as high moisture $(\mathbf{H M}$; overall mean $=$ $58.3 \%$ ) and the second bale was made approximately $3 \mathrm{~h}$ later at an ideal bale moisture for this silage type $(\mathbf{I M}$, overall mean $=44.9 \%)$. A total of 47 bales were made during the experiment; one orchardgrass plot had insufficient forage to produce 2 bales.

\section{DM Yield from Grass Plots}

At $1000 \mathrm{~h}$ on June 29, the DM yield from the 24 grass plots was assessed with a self-propelled, flail-type forage plot harvester with a cutting width of $1.07 \mathrm{~m}$; the plot harvester was equipped with a large-capacity weigh box, load cells, and digital weight read-out display. To determine DM yield, each plot was visually divided in half along the longer dimension of the 14.6 $\times 153.8 \mathrm{~m}$ plot, and then one $(\sim 8 \mathrm{~m})$ swath was taken from a randomly chosen location within each half-plot. A wet plot weight and grab sample $(\sim 390 \mathrm{~g})$ were obtained from each harvested swath; grab samples were dried for $72 \mathrm{~h}$ in paper bags under forced air at $55^{\circ} \mathrm{C}$ to determine the DM concentration of each grass at harvest. Yields of DM were calculated from swath area, wet plot weights, and concentrations of DM. Results from the 2 swaths per plot were averaged to obtain a final DM yield and DM concentration (reported as \% moisture) for the forage harvested from each plot.

\section{Baling Procedures}

Between 1000 and $1230 \mathrm{~h}$ on June 29, all 24 plots were mowed and conditioned with a Case-International Harvester Model 8830 self-propelled mower/conditioner (J. I. Case Co., Racine, WI) that was equipped with intermeshing metal conditioning rollers. This model mower/conditioner was also equipped with a $3.65-\mathrm{m}$ wide cutting platform and a sickle-bar-style cutting mechanism. Stubble height and swath width following mowing were $12 \pm 1.6$ and $172 \pm 5.9 \mathrm{~cm}$, respectively. Forages were allowed to wilt, undisturbed, without rain damage, until $1400 \mathrm{~h}$ when one $1.2 \times 1.2 \mathrm{~m}$ round bale (moisture group HM) was produced from each plot with a New Holland Roll-Belt 450 round baler (CNH America LLC, Racine, WI), which comes equipped with 15 cutting knives that can be engaged/disengaged remotely by the operator in the cab of the tractor. Baling procedures were conducted by field block, such that cut and uncut bales were produced in a random order within each block based on a priori treatment assignments. These procedures eliminated any potential confounding, particularly with respect to bale moisture, which could have been created by baling all of one bale type before the other. A constant $8.9 \mathrm{~km} / \mathrm{h}$ ground speed was maintained during the baling of all plots, and 3.5 revolutions of net wrap were used to tie each bale before it was discharged from the baler. For the HM category, $1.4 \mathrm{~h}$ of elapsed time was required to produce the initial 24 bales.

Each bale was tagged for identification, weighed on a platform scale $( \pm 0.45 \mathrm{~kg})$, and measured for width, as well as diameter in vertical, horizontal, and diagonal orientations. The 3 measurements of diameter were averaged before calculating bale volume. Before bales were wrapped in polyethylene, three 0.61 -m-deep core samples $(0.025 \mathrm{~m}$ diameter $)$ were obtained from one side of each bale with a Uni-Forage Sampler (Star Quality Samplers, Edmonton, AB, Canada) fitted to an electric drill. Each sampling hole was purged of air with spray-foam insulation, but any subsequent contact between the insulation and polyethylene bale wrap was not permitted. After initial bale sampling, a Model 995 TSR bale wrapper (McHale Engineering Limited, Ballinrobe, Co. Mayo, Ireland) was programmed to apply 7 polyethylene film layers of Flavor-Seal White Poly Stretch Film (Benco Poly Film LLC, Leola, PA) that was $750 \mathrm{~mm}$ wide and $25.4 \mu \mathrm{m}$ thick (unstretched). The 24 bales in the HM grouping were wrapped at 1530 $\mathrm{h}$, with all wrapping completed and bales positioned on a concrete pad by $1715 \mathrm{~h}$. Similar procedures were used for the IM bale moisture grouping; baling occurred for this grouping between 1715 and $1830 \mathrm{~h}$, and bales were sampled, wrapped, and positioned on the concrete pad by $2000 \mathrm{~h}$.

Initial core samples obtained from HM and IM bales were composited within bale and placed in 3.8-L plastic freezer bags. All samples were stored on ice inside an insulated cooler and then transported to the laboratory for subsequent analysis. After thorough mixing, a 25-g subsample from each freezer bag was dried overnight under forced air at $105^{\circ} \mathrm{C}$ to determine the initial mois- 
ture concentration within each bale. The remaining sample from each bale was placed in an ultralow freezer $\left(-80^{\circ} \mathrm{C}\right)$ to quickly suspend respiration and stored under those conditions pending all further processing and analysis procedures.

\section{Postensiled Sampling}

On the termination date of the trial (October 18), bales were weighed on a platform scale as described previously, and 6 to 9 core samples $(0.61 \mathrm{~m}$ deep $\times$ $0.025 \mathrm{~m}$ diameter $)$ were obtained from each bale $(300$ to $400 \mathrm{~g}$ /bale; wet basis). Final core sampling sites were spaced across the circumferential surface of the bale, covering an area $100^{\circ}$ from top center on both sides of the bale; however, this orientation was established after weighing and was not necessarily consistent with the bale orientation during the 111-d storage period. Core samples were processed as described previously for the initial bale sampling, except that a larger (40-g) subsample was dried overnight in a forced-air oven at $105^{\circ} \mathrm{C}$ to determine the final moisture concentration of each silage bale. The balance of each sample $(\sim 300 \mathrm{~g}$; wet basis) was placed in an ultralow freezer $\left(-80^{\circ} \mathrm{C}\right)$ to suspend respiration, and stored there pending further processing and subsequent analysis for nutritive value, $\mathrm{pH}$, and silage fermentation products.

\section{Laboratory Analyses}

Preensiled Forage. Preensiled forage samples stored in the ultralow freezer were thoroughly mixed, and a 25-g subsample was used to determine the initial $\mathrm{pH}$ of each bale following suspension in $100 \mathrm{~mL}$ of deionized water, and then $30 \mathrm{~s}$ of maceration in a kitchen blender. The resulting slurry was filtered through 2 layers of cheese cloth, and the $\mathrm{pH}$ was recorded with a bench-top $\mathrm{pH}$ meter. The remaining sample from each bale was lyophilized and then ground to pass through a 1-mm screen within a Thomas Model 4 Wiley Mill (Thomas Scientific, Swedesboro, NJ). Preensiled (initial) concentrations of WSC were determined by extracting $0.25 \mathrm{-g}$ subsamples for $2 \mathrm{~h}$ in $150 \mathrm{~mL}$ of deionized water. After $2 \mathrm{~h}$, the slurry was gravity filtered through Whatman \#1 filter paper, and the phenol-sulfuric acid reaction (DuBois et al., 1956) was used to quantify WSC. Final concentrations of WSC were determined using a double-beam spectrophotometer, with dextrose used to formulate standards. The $\mathrm{BC}$ of each bale was determined via titration and reported as milliequivalents of $\mathrm{HCl}$ per kilogram of forage $\mathrm{DM}$ needed to reduce $\mathrm{pH}$ from 6.0 to 4.0 (Muck and Walgenbach, 1985; Coblentz and Muck, 2012).
Postensiled Forage. Silage samples from each bale were processed, and analyzed for $\mathrm{pH}$ and WSC exactly as described for preensiled evaluations; however, BC was not determined after the 111-d storage period. Before core samples were processed (freeze-dried and ground), a 100-g subsample was shipped to Cumberland Valley Analytical Services (Waynesboro, PA), where concentrations of various fermentation products were determined by an extraction of each silage in deionized water $(12.5 \% \mathrm{wt} / \mathrm{vol})$, and subsequent gravity filtration through coarse filter paper. Each extract was evaluated for acetic, propionic, and butyric acids by gas chromatography (PerkinElmer AutoSystem, PerkinElmer Inc., Shelton, CN), lactic acid (YSI 2700 Select Biochemistry Analyzer, YSI Inc., Yellow Springs, $\mathrm{OH}$ ), and $\mathrm{NH}_{3}-\mathrm{N}$ (Labconco Rapidstill II Model 65200 Analyzer, Labconco, Kansas City, MO). For determination of total lactic acid, the silage extract was diluted further by doubling the volume with deionized water. Furthermore, the YSI 2700 Analyzer detects only Llactic acid; therefore, total lactic acid concentrations were calculated as L-lactic acid $\times 4$.

Nutritive Value. Laboratory DM concentrations of dried, ground forages were assessed by placing 1.0-g samples in a convection oven overnight at $105^{\circ} \mathrm{C}$. In addition, whole-plant ash was determined on 1.0-g samples of each forage by combustion in a muffle furnace for $6 \mathrm{~h}$ at $500^{\circ} \mathrm{C}$. Batch procedures outlined by Ankom Technology Corp. (Macedon, NY) for an ANKOM200 Fiber Analyzer were used to sequentially analyze dried, ground, pre- and postensiled samples for NDF, ADF, and ADL; however, no sodium sulfite or heat-stable $\alpha$-amylase were included in the neutral-detergent procedures, thereby permitting an accurate determination of ADL (Van Soest et al., 1991). To calculate in vitro NDF digestibility on an ash-corrected basis, a separate evaluation of NDF was conducted with $\alpha$-amylase and sodium sulfite, and with subsequent correction for residual ash (asNDFom) by combustion of NDF residues for $6 \mathrm{~h}$ at $500^{\circ} \mathrm{C}$. Rapid combustion procedures were used for all analyses of N (AOAC International, 1998, official method 990.03; Model TruMac CN, Leco Corp., St. Joseph, MI), and a conversion factor of 6.25 was used to convert total $\mathrm{N}$ to $\mathrm{CP}$. Neutral-detergent (NDICP) and acid-detergent (ADICP) insoluble CP were calculated based on insolubility of $\mathrm{CP}$ following nonsequential digestion in each respective solution. No sodium sulfite or heat-stable $\alpha$-amylase were used during the initial digestion of forages for determination of NDICP; sodium sulfite was omitted because it removes $\mathrm{CP}$ from NDF residues, thereby resulting in an underestimated final concentration of NDICP (Van Soest et al., 1991). Calculation of $\mathrm{NE}_{\mathrm{L}}$ was accomplished per 
equations of NRC (2001), in which the ADL option was used to estimate truly digestible fiber.

In Vitro Digestibility of asNDFom. In vitro digestibilities of DM (IVDMD) and asNDF om (NDFD) were determined in triplicate on 0.25 -g subsamples of each pre- and postensiled forage based on a 30-h incubation. In vitro incubations were conducted with the

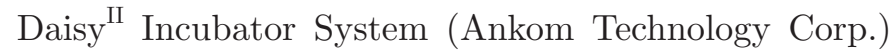
per the recommended procedures of the manufacturer (Ankom Technology, 2017). Subsamples of each forage were heat-sealed within F57 fiber bags (pore size = $25 \mu \mathrm{m}$; Ankom Technology Corp.) using an impulse sealer (model \#AIE-200, American International Electric, City of Industry, CA). Empty F57 filter bags were pre-rinsed in acetone, and then air-dried consistent with manufacturer instructions. Each incubation jar within the Daisy ${ }^{\mathrm{II}}$ Incubator System can accommodate 24 samples, one standard and one blank; as such, all pre- and postensiled samples $(\mathrm{n}=94)$ were incubated within a single incubator box or unit, but pre- and postensiled samples were not co-mingled within the same incubation jars. Three incubator units were available; therefore, each sample was incubated in triplicate simultaneously with rumen fluid obtained from 2 nonlactating Holstein donor cows.

Procedures for care and maintenance of donor cows were approved by the Research Animal Resources Committee of the University of Wisconsin-Madison (protocol \#A01006). Cows were offered a diet for ad libitum intake comprising (DM basis) corn silage $(53.2 \%)$, wheatlage $(31.9 \%)$, soybean meal $(13.5 \%)$, and minerals $(1.4 \%)$, which was formulated to include $39.0 \% \mathrm{NDF}, 13.1 \% \mathrm{CP}$, and $1.48 \mathrm{Mcal}$ of $\mathrm{NE}_{\mathrm{L}} / \mathrm{kg}$. Rumen fluid was siphoned from each donor cow with a hand-operated pump, where access to the rumen was gained through a ruminal cannula. Fluid from each cow was pumped into prewarmed $\left(39^{\circ} \mathrm{C}\right)$ insulated bottles, and then transported to the research laboratory in a chest-type insulated cooler. Rumen fluid was filtered through 4 layers of cheesecloth, and $400 \mathrm{~mL}$ of rumen fluid with approximately equal contributions from both donor cows was added to each incubation jar containing buffers and samples prewarmed to $39^{\circ} \mathrm{C}$. Within each incubation jar, the head-space was purged with $\mathrm{CO}_{2}$ initially after buffers and sample bags were added to the incubation jars, and again a second time immediately following the addition of the rumen fluid just before final lid placement. Samples, standards, and blanks were incubated for $30 \mathrm{~h}$, and then rinsed per recommendations of the manufacturer; subsequently, they were dried to constant weight under forced air at $55^{\circ} \mathrm{C}$, and weighed to determine residual DM. After weighing, bags containing standards were dried over- night under forced air at $105^{\circ} \mathrm{C}$ to establish a mean additional weight loss by drying to absolute DM. This was used as a correction factor in calculations of IVDMD to avoid drying $\mathrm{DM}$ residues at $105^{\circ} \mathrm{C}$ before analyzing for residual as NDFom. Following these procedures, sample bags were digested in neutral detergent using heatstable $\alpha$-amylase and sodium sulfite. Residual NDF was dried overnight in a convection oven at $105^{\circ} \mathrm{C}$, weighed, and then placed in a muffle furnace at $500^{\circ} \mathrm{C}$ for 6 $\mathrm{h}$ to allow correction of the residual fiber weight for contaminant ash (asNDFom). The triplicate values for each pre- and postensiled sample were considered to be multiple within-sample observations, and averaged to obtain a final IVDMD or NDFD value for each sample.

\section{Statistics}

The moisture concentration of standing forage and DM yield did not include treatment factors of bale cutter engagement or initial bale moisture category, and these response variables were analyzed as a randomized complete block design with forage types as treatments. Within this context, each of the 4 field blocks had 2 entries per forage type. Mean separation between forage types was accomplished using the pdiff option within PROC MIXED of SAS (version 9.4, SAS Institute Inc., Cary, NC). Initial and final bale characteristics, silage fermentation products, as well as pre- and postensiled nutritive value also were analyzed by PROC MIXED of SAS, but the overall experimental design was a splitplot, with a $3 \times 2$ factorial arrangement of forage type (meadow fescue, orchardgrass, or tall fescue) and balecutting engagement (cut or uncut) as the whole-plot portion of the design. Moisture category (HM or IM) was treated as the sub-plot term. Mean separation was accomplished through the pdiff option in SAS. Throughout this experiment, interactions of main effects were rarely significant at the $P \leq 0.05$ level of confidence; on this basis, most data are reported and discussed as main-effect means only. When interactions of main effects occurred that were important in explaining results, interaction means were compared similarly with the pdiff option. Statistical significance was declared at the $P \leq 0.05$ level of confidence; tendencies $(P \leq$ 0.10 ) were noted if they contributed significantly to an explanation of research results.

\section{RESULTS AND DISCUSSION}

\section{Unique Observation}

A unique observation was noted for orchardgrass in this experiment; although this harvest represented the 
first cutting of the year, plants were entirely vegetative, and (morphologically) completely unlike meadow fescue or tall fescue, both of which were fully headed. Orchardgrass is known to behave as a short-day-longday plant (Heide, 1987) with dual requirements for flowering that include short days for floral induction, followed by long days for floral initiation. This process is further complicated by interactions with temperature (Heide, 1987; Casler et al., 2004), prompting Berg et al. (1981) to conclude that reproductive tiller production is controlled by a complex interaction of genetic and environmental factors. These factors can result in marked differences in reproductive performance by the same cultivar grown in different locations, or by the same cultivar grown in the same location during different years (Hovin et al., 1966). Recently, efforts to limit flowering by intentional manipulation of these concepts have been reported, primarily to facilitate improved utilization and management of orchardgrass within intensively managed pastures (Casler et al., 2004). In that work, it was theorized that winter (shortday) temperatures are the most likely regulating factor, and that floral-regulating genes are likely turned off by temperatures below a critical level for flowering. Furthermore, it was concluded that expression of this trait is variable, with some plants being somewhat sensitive (sparse-flowering), whereas others are highly sensitive (nonflowering). For the present study, mean monthly temperatures for November and December 2017 provided by the University of Wisconsin Marshfield Agricultural Research Station were below normal by 1.1 and $1.3^{\circ} \mathrm{C}$, respectively. However, the mean monthly temperature during April $2018\left(0.4^{\circ} \mathrm{C}\right)$ was $6^{\circ} \mathrm{C}$ below normal; furthermore, the research site received $711 \mathrm{~mm}$ of snowfall during the month, including 4 events of at least $152 \mathrm{~mm}$. Cumulative snowfall for April 2018 was $640 \mathrm{~mm}$ above normal. We can only speculate that a combination of unique climatic conditions during the fall/winter/early spring of 2017-2018 in Stratford (WI), coupled with the genetic controls within Echelon orchardgrass, triggered the described nonflowering (vegetative) growth response.

\section{DM Yield}

First-cutting yields of perennial cool-season grasses in this trial were affected $(P<0.001)$ by forage type, with both meadow and tall fescues exceeding $(P<$ $0.001)$ the yield of orchardgrass $(2,977 \mathrm{~kg}$ of DM/ha) by $\geq 84 \%$ (Figure 1). First-cutting DM yields of meadow and tall fescue did not differ (5,580 vs. $5,763 \mathrm{~kg}$ of DM/ ha; $P=0.515$ ). In a previous study (Brink and Casler, 2009), tall fescue and orchardgrass produced greater

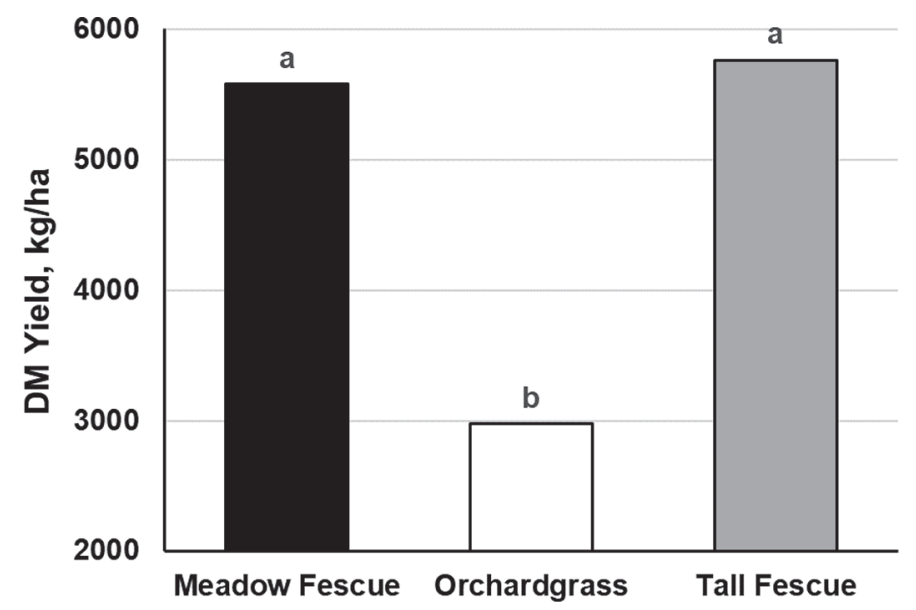

Figure 1. First-cutting DM yields for perennial grass forages at Stratford, Wisconsin; SEM $=366.9 \mathrm{~kg} / \mathrm{ha} .{ }^{\mathrm{a}, \mathrm{b}}$ Both meadow and tall fescue differed $(P<0.001)$ from orchardgrass, but they did not differ $(P=0.515)$ from each other.

annual yields than meadow fescue during the second production year, but not necessarily during the initial production year. In another study assessing defoliation management (Brink et al., 2010), annual DM yields of tall fescue and orchardgrass were greater than observed for meadow fescue when forages were harvested infrequently. However, yield differences were reduced with frequent harvests, and especially when a $10-\mathrm{cm}$ residual sward height was maintained. Similarly, DM yields did not generally differ between meadow fescue and orchardgrass when a seasonal (spring, summer, and fall) harvest schedule at a $10-\mathrm{cm}$ stubble height was evaluated (Brink et al., 2008). Within the present study, differences in yield between orchardgrass and the other forages is likely explained by the nonflowering trait expressed by the Echelon cultivar during the spring of 2018, which resulted in the total absence of any developed stems in the forage.

\section{Bale Characteristics}

Preensiled. Neither forage type $(P=0.718)$ nor cutter engagement $(P=0.179)$ affected initial bale width (Table 1$)$. Moisture category yielded a significant $(P=$ 0.023) effect for initial bale width, although the magnitude of this response was small and of no obvious practical relevance. Initial bale diameter and volume were greater $(P \leq 0.002)$ for meadow and tall fescue compared with orchardgrass bales, and were greater $(P$ $\leq 0.005)$ for HM compared with IM bales. In general, orchardgrass bales were about $0.11 \mathrm{~m}^{3}$ smaller in volume than bales from other forages, and IM bales that were smaller than HM bales by about half that amount. 
Because bale diameter can be monitored electronically from the cab of the tractor, these small differences in bale volume may reflect marginally inadequate forage in some orchardgrass plots necessary to produce 2 full-size (1.2-m diameter) bales, and not any obvious inherent physical characteristics of orchardgrass forages. Logically, small differences in bale volume would be most evident for IM bales, which represent the second bale produced in each plot after an extended wilting period.

A forage type $\times$ moisture category interaction $(P=$ 0.031 ) was detected for initial bale moisture (Figure $2)$. No differences $(P \geq 0.223)$ were observed between forages within the high moisture category, but for the ideal category, all forages differed from each other $(P$ $\leq 0.050)$, with meadow fescue wettest $(48.2 \%)$ and orchardgrass driest (41.9\%). The drier nature of orchardgrass forages reflects more rapid field wilting that is likely explained by swaths that were less dense, and with a complete absence of stem tissue. Brink et al. (2014) compared the field drying rates of 3 cool-season grasses [meadow fescue, orchardgrass, and reed canarygrass (Phalaris aruninacea L.)] grown in southern Wisconsin, and concluded that forage species likely has little effect on drying rates. Although windrow densities and leaf-to-stem ratios varied across forages in

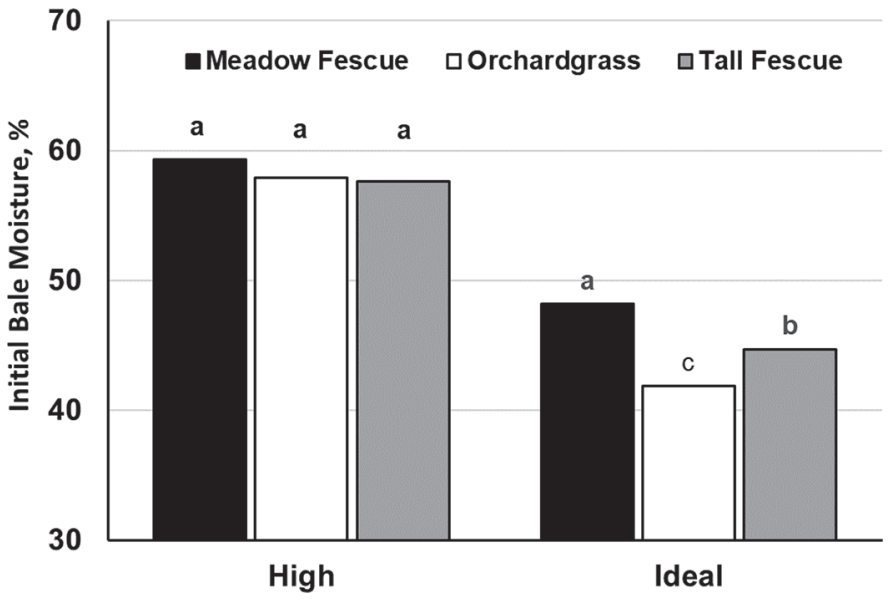

Figure 2. Interaction $(P=0.031)$ of forage type and moisture category for the initial bale moisture of 3 perennial cool-season forage grasses. Within moisture category, forages without common letters differed from each other at $P \leq 0.050$. No differences $(P>0.223)$ were observed between forages within the high-moisture category. Pooled $\mathrm{SEM}=0.94 \%$ for the interactive means.

that study, the nonflowering response reported for our orchardgrass forages was not observed. Unlike other treatment factors, cutter engagement had no effect $(P$ $=0.926)$ on initial bale moisture.

Table 1. Pre- and poststorage bale characteristics for 47 round bales of perennial cool-season grasses ensiled for $111 \mathrm{~d}$ near Stratford, Wisconsin

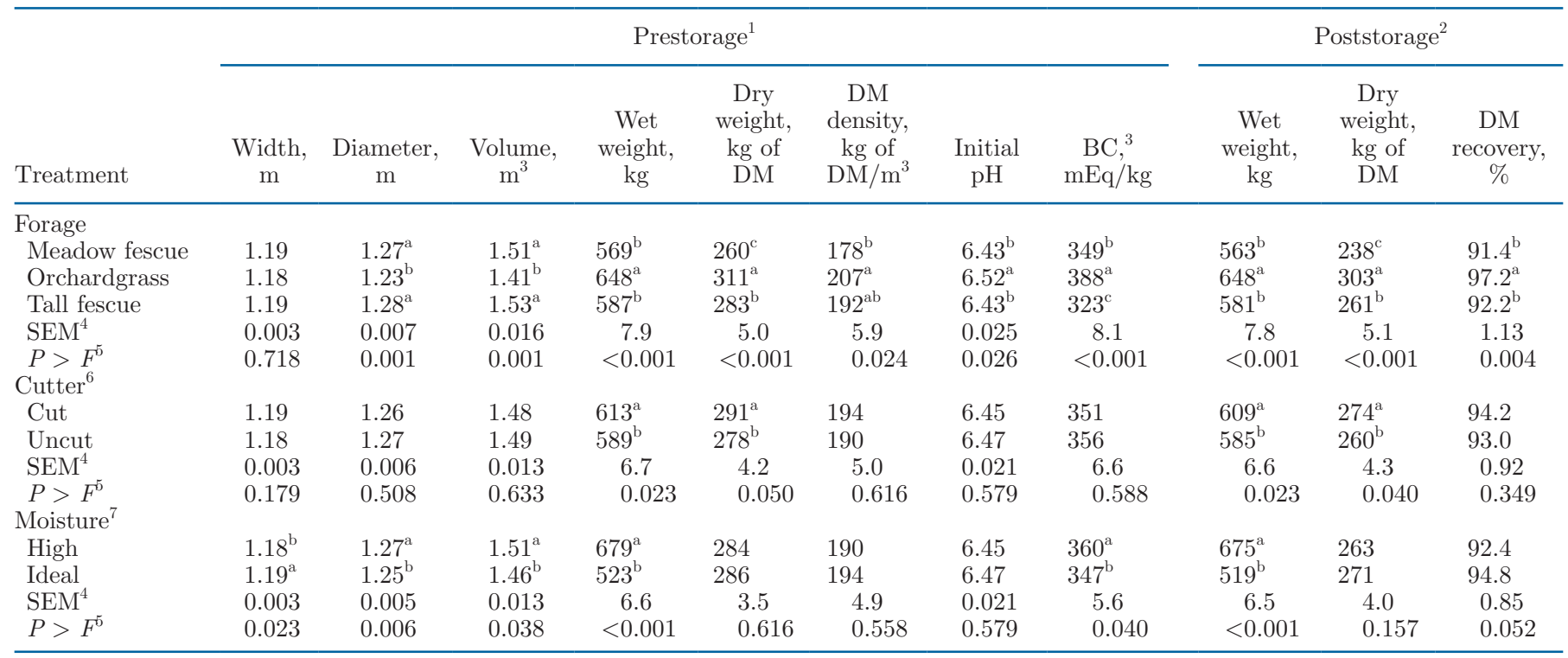

${ }^{\mathrm{a}-\mathrm{c}}$ Means within a column and main effect without common superscripts differ at $P \leq 0.05$.

${ }^{1}$ Bales sampled immediately after baling.

${ }^{2}$ Bales sampled after a 111-d fermentation.

${ }^{3} \mathrm{BC}=$ buffering capacity.

${ }^{4}$ Pooled SE of the main-effect mean.

${ }^{5}$ Test of significance for the main-effect mean.

${ }^{6} \mathrm{Cut}=$ bales made with bale-cutting system engaged; uncut $=$ bales made without particle-length reduction.

${ }^{7}$ High-moisture mean across all baling treatments was $58.3 \%$; for ideal moisture, the mean across all treatments was $44.9 \%$. 
Wet bale weights were greater $(P<0.001)$ for orchardgrass by 61 and $79 \mathrm{~kg}$ compared with tall and meadow fescue, respectively; this observation also is likely related to the totally vegetative nature of the orchardgrass forage, and large differences in DM yield noted previously (Figure 1) between orchardgrass and the other forages. Baler operation was maintained at a constant $8.9 \mathrm{~km} / \mathrm{h}$ ground speed; therefore, the reduced yield of orchardgrass resulted in more bale revolutions within the chamber, and increased bale density. Engagement of the bale cutter also had a positive effect on initial wet bale weights ( 613 vs. $589 \mathrm{~kg} ; P=0.023$ ), or an approximate $4.1 \%$ increase, which is almost identical to a response in bales made from an alfalfa-grass mixture with the same equipment (4.2\%; Coblentz and Akins, 2019). On a dry weight basis, the 3 forage types all differed $(P \leq 0.005)$ from each other, with orchardgrass bales containing $51 \mathrm{~kg}$ of DM more forage than meadow fescue (311 vs. $260 \mathrm{~kg}$ of DM), and tall fescue (283 $\mathrm{kg}$ of DM) being intermediate between these extremes. Engagement of the bale cutter increased $(P=0.050)$ bale dry weights by $13 \mathrm{~kg}(4.7 \%)$ compared with uncut bales. This response to cutter engagement exceeded a $3.2 \%$ increase that was not statistically significant in our previous work (Coblentz and Akins, 2019). In the present work, the DM density of bales was not affected by bale-cutter engagement (overall mean $=192 \mathrm{~kg}$ of $\left.\mathrm{DM} / \mathrm{m}^{3} ; P=0.616\right)$, but orchardgrass exceeded $(P=$ 0.008 ) those made of meadow fescue by $29 \mathrm{~kg}$ of DM/ $\mathrm{m}^{3}$. Previously, Borreani and Tabacco (2006) reported a $4 \%$ increase in DM density, based on a series of trials in which bales were cut with a 15 -knife system spaced at $93 \mathrm{~mm}$; however, we observed only a small numerical advantage $\left(4 \mathrm{~kg}\right.$ of $\left.\mathrm{DM} / \mathrm{m}^{3}\right)$ for cut bales in our previous work with alfalfa-grass mixtures (Coblentz and Akins, 2019). Regardless, the overall mean of $192 \mathrm{~kg}$ of $\mathrm{DM} / \mathrm{m}^{3}$ for bales in this study exceeds the suggested $162 \mathrm{~kg}$ of $\mathrm{DM} / \mathrm{m}^{3}$ target density for good baled silage management suggested by Jennings (2011).

For initial $\mathrm{pH}$, a significant main effect of forage type was detected $(P=0.026)$. Individually, orchardgrass $(\mathrm{pH}=6.52)$ was $0.09 \mathrm{pH}$ units less acidic than either meadow $(P=0.016)$ or tall $(P=0.019)$ fescue, which were almost identical $(\mathrm{pH}=6.43 ; P=0.931)$. Other treatment factors had no effect $(P=0.579)$ on initial forage $\mathrm{pH}$. Similarly, BC was affected only by forage type $(P<0.001)$, where orchardgrass was the most highly buffered forage $(388 \mathrm{mEq} / \mathrm{kg}$ of $\mathrm{DM})$, followed by meadow and tall fescue ( 349 and $323 \mathrm{mEq} / \mathrm{kg}$ of DM, respectively), all of which were statistically distinct $(P$ $\leq 0.033$ ). Generally, buffering properties of forages are attributed to the anions present from organic acid salts, orthophosphates, sulfates, nitrates, and chlorides, where the most important organic acids in grasses are malic, citric, and quinic acids (McDonald et al., 1991). Furthermore, the BC of forages generally declines with maturity for both grasses (McDonald et al., 1991; Muck et al., 1991), as well as alfalfa (Muck and Walgenbach, 1985). Muck et al. (1991) reported that pasture grasses exhibited a $20 \mathrm{mEq} / \mathrm{kg}$ of $\mathrm{DM}$ decline in $\mathrm{BC}$ per week beginning 2 to 3 wk before seedhead emergence when $\mathrm{BC}$ ranged initially from 400 to $450 \mathrm{mEq} / \mathrm{kg}$ of DM. In addition, Muck and Walgenbach (1985) observed that greater BC was associated strongly with leaf tissue, and anything that reduced leaf-to-stem ratios within alfalfa forages (such as maturity) also reduced BC. Furthermore, reductions in $\mathrm{BC}$ have been observed within moderately or severely rain-damaged alfalfa relative to the initial BC within standing forages (Coblentz and Muck, 2012). For the present study, differences in BC among forage types may be mostly related to plant maturity; orchardgrass was completely vegetative at harvest, whereas meadow fescue is commonly observed to mature more slowly than tall fescue throughout Wisconsin.

Postensiled. Final wet bale weights (Table 1) were affected by forage type $(P<0.001)$, cutter engagement $(P=0.023)$, and moisture category $(P<0.001)$ with separation of treatments identical to that observed on a preensiled basis. Similarly, mean separation for dry bale weights as affected by forage type $(P<0.001)$ and cutter engagement $(P=0.040)$ followed the same patterns as observed on a preensiled basis; however, HM and IM groupings did not differ $(P=0.157)$. Averaged across all forages, recoveries of DM following storage were $>93 \%$, thereby indicating good integrity of the polyethylene bale wraps throughout the 111-d storage period. Only the main effect $(P=0.004)$ of forage type affected DM recoveries; orchardgrass (97.2\%) exhibited greater $(P \leq 0.007)$ recovery than meadow or tall fescue, which did not differ $(P \geq 0.591)$. An interaction of forage type and moisture category $(P=0.002)$ was detected for final bale moisture (Figure 3). For HM bales, meadow fescue $(62.3 \%)$ was greater $(P=0.007)$ than orchardgrass $(59.2 \%)$, but neither forage differed $(P \geq 0.127)$ from tall fescue $(60.7 \%)$; however, all forages were statistically distinct for IM bales $(P \leq 0.001)$. When considered against preensiled concentrations of bale moisture, final bale moistures increased for tall and meadow fescue by $\geq 3.0$ and 2.5 percentage units within the HM and IM categories, respectively, but by $\leq 1.3$ percentage units for orchardgrass. Although somewhat circumstantial, these results are consistent with the greater DM bale densities and DM recoveries observed for orchardgrass silages; respiratory processes, often occurring during the slow ensiling of forages, or 
due to poor or compromised sealing techniques, produce water as an end product (Muck, 1988).

\section{Nutritive Value}

Preensiled. The main effect of bale-cutter engagement did not affect $(P \leq 0.158)$ any measure of forage nutritive value on a preensiled basis (Table 2), and moisture category affected only concentrations of wholeplant ash $(P=0.001)$, ADICP $(P=0.030)$, and $\mathrm{NE}_{\mathrm{L}}$ $(P=0.001)$. For ash and ADICP, concentrations were greatest for HM bales, but the opposite relationship was observed for $\mathrm{NE}_{\mathrm{L}}$; however, the magnitude of these differences was small in all cases, and of questionable practical relevance. In contrast to the minimal effects of cutter engagement and moisture category, the main effect of forage type affected $(P \leq 0.013)$ all indices of nutritive value except $\mathrm{ADL}$ (overall mean $=2.85 \%$; $P=0.119)$. Concentrations of WSC varied between forages; tall fescue exhibited the greatest $(P \leq 0.002)$ concentration (10.73\%), which was more than twice that of orchardgrass (5.15\%). Although concentrations of NDF and ADF varied with forage type, the overall respective ranges were narrow (60.9 to 62.7 and 35.2 to $36.4 \%$ ); the relatively minor differences in fiber composition between these forages are noteworthy considering the nonflowering response of the orchardgrass forages during June 2018. Orchardgrass regrowth (vegetative) has exhibited concentrations of NDF in excess of $60 \%$ during studies conducted in Arkansas (Scarbrough et al., 2005), but reached only $55.4 \%$ at full inflorescence

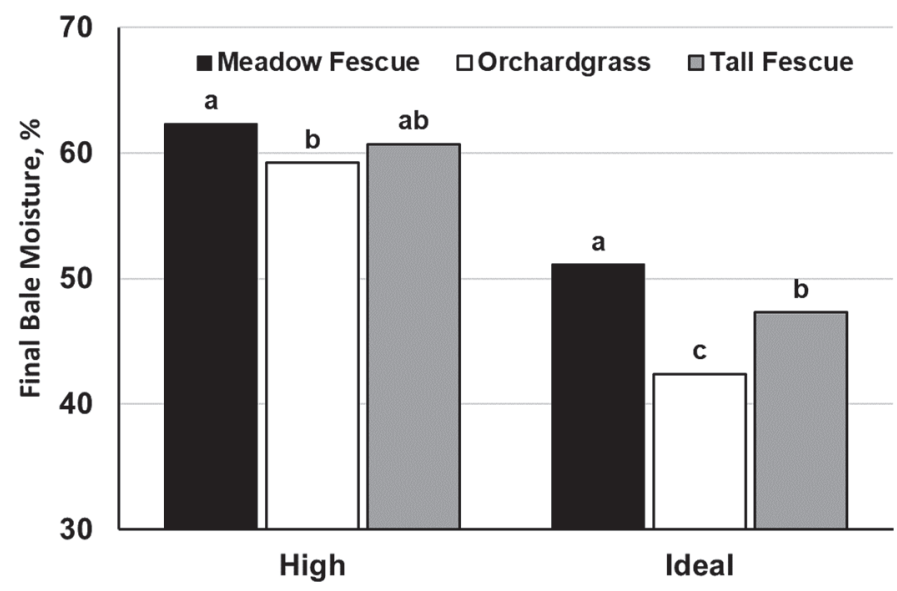

Figure 3. Interaction of forage type and moisture category $(P=$ $0.002)$ for final bale moisture after $111 \mathrm{~d}$ in storage. Mean separation is by moisture category. ${ }^{\mathrm{a}-\mathrm{c}}$ Within the high-moisture category, meadow fescue was greater than orchardgrass $(P=0.007)$, but neither forage differed from tall fescue $(P \geq 0.127)$; for the ideal moisture category, each forage was statistically distinct $(P \leq 0.001)$. Pooled SEM = $0.71 \%$ for the interactive means. in a study conducted in a similar central Wisconsin environment (Hoffman et al., 1993). Several studies (Brink et al., 2007; Brink et al., 2010; Schaefer et al., 2014) have suggested that meadow fescue often exhibits reduced NDF compared with tall fescue or orchardgrass (or both) when evaluated over a wide range of management options; however, such a response was not observed in the present experiment. Concentrations of whole-plant ash were statistically distinct $(P \leq 0.001)$ across forage types, greatest for orchardgrass $(11.3 \%)$ and least for tall fescue $(8.2 \%)$. It is not uncommon to observe declining concentrations of ash during plant maturation, such as those observed in a recent study evaluating triticale (X Triticosecale Wittmack) across a wide range of growth stages (Coblentz et al., 2018), and this may explain the greater ash concentrations in nonflowering orchardgrass compared with meadow and tall fescue.

Total CP, NDICP, and ADICP (Table 2) all were affected by forage type $(P \leq 0.005)$, and in each case, concentrations in orchardgrass were greatest $(P$ $\leq$ 0.008); responses for other forages were generally similar in magnitude. Although concentrations of $\mathrm{CP}$ in harvested grasses often are affected by $\mathrm{N}$ fertilization rate, there was no confounding of this management input within this experiment. It is likely that the greater $\mathrm{CP}$ in orchardgrass (10.1\%) compared with meadow $(7.1 \%)$ or tall fescue $(7.5 \%)$ was related directly to the nonflowering growth response. Previously, Casler et al. (2014) determined that sparse-flowering orchardgrass cultivars grown across 21 sites in North America exhibited $9 \%$ greater CP than normal flowering cultivars; however, those cultivars exhibited mean densities of 61 and 141 panicles $/ \mathrm{m}^{2}$, both of which are far greater numbers than those observed for the complete nonflowering response in this trial. Calculated energy density $\left(\mathrm{NE}_{\mathrm{L}}\right)$ was greatest $(P<0.001)$ for meadow and tall fescue compared with orchardgrass (1.40 vs. $1.34 \mathrm{Mcal} /$ $\mathrm{kg}$ ), which may be a computational artifact of greater concentrations of ash and ADICP within the orchardgrass (NRC, 2001).

Postensiled. Poststorage nutritive value is summarized in Table 3. Although some differences are present in treatment effects, and with respect to mean separation among forage types, various nutritive indices generally do not represent substantial changes from preensiled concentrations. One exception is residual WSC, which were reduced by 30.4 to $47.7 \%$ for the 3 forage types. Furthermore, reductions in WSC during silage fermentation were greater for HM (45.9\%) compared with IM bales (29.3), suggesting an expected more aggressive silage fermentation within wetter HM bales. Nicholson et al. (1991) demonstrated the inter- 
Table 2. Nutritive value for baled perennial grass forages sampled on a preensiled basis during 2018, near Stratford, Wisconsin

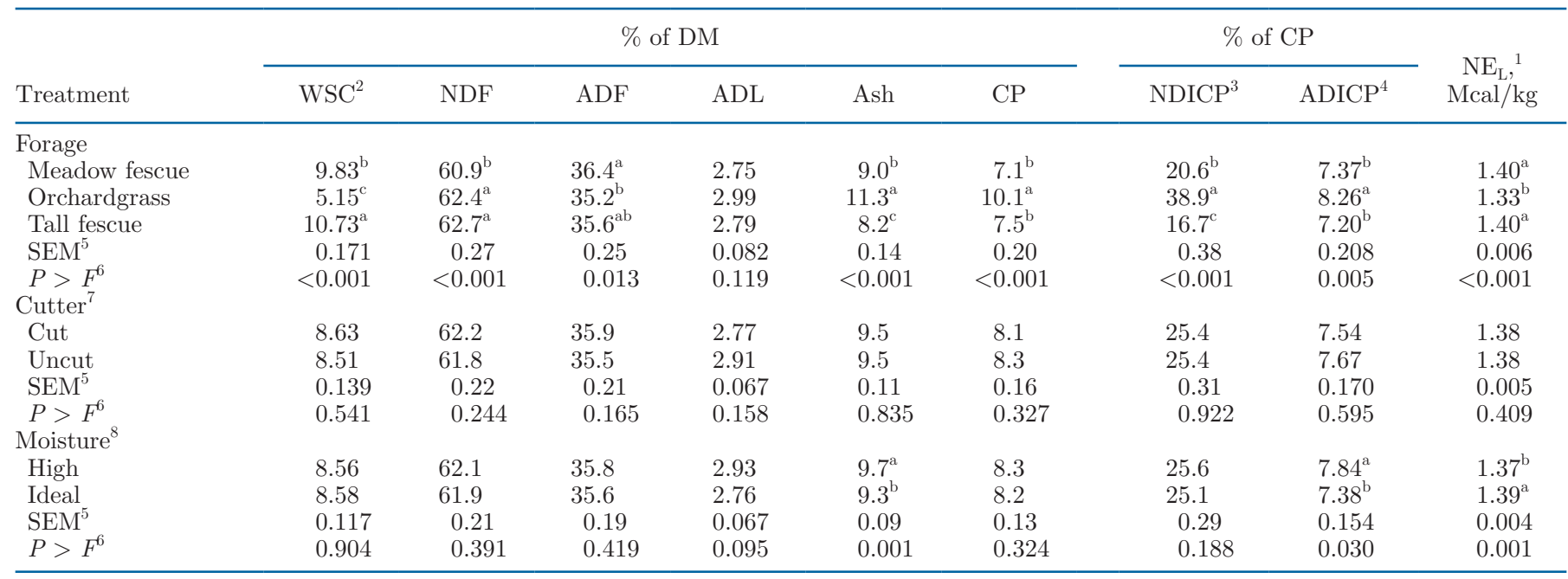

${ }^{\mathrm{a}-\mathrm{c}}$ Means within a column and main effect without common superscripts differ at $P \leq 0.05$.

${ }^{1} \mathrm{NE}_{\mathrm{L}}$ calculated per NRC (2001) recommendations with the ADL option used to calculate truly digestible fiber.

${ }^{2} \mathrm{WSC}=$ water-soluble carbohydrates.

${ }^{3} \mathrm{NDICP}=$ neutral-detergent insoluble CP.

${ }^{4} \mathrm{ADICP}=$ acid-detergent insoluble $\mathrm{CP}$.

${ }^{5}$ Pooled SE of the main-effect mean.

${ }^{6}$ Test of significance for the main-effect mean.

${ }^{7} \mathrm{Cut}=$ bales made with bale-cutting system engaged; uncut $=$ bales made without particle-length reduction.

${ }^{8}$ High-moisture mean across all baling treatments was $58.3 \%$; for ideal moisture, the mean across all treatments was $44.9 \%$.

Table 3. Nutritive value for baled perennial grass silages sampled after $111 \mathrm{~d}$ of storage during 2018 near Stratford, Wisconsin

\begin{tabular}{|c|c|c|c|c|c|c|c|c|c|}
\hline Treatment & \multicolumn{6}{|c|}{$\%$ of DM } & \multicolumn{2}{|c|}{$\%$ of $\mathrm{CP}$} & $\begin{array}{c}\mathrm{NE}_{\mathrm{L}},{ }^{1} \\
\text { Mcal/kg }\end{array}$ \\
\hline \multicolumn{10}{|l|}{ Forage } \\
\hline Orchardgrass & $3.43^{\mathrm{c}}$ & $61.6^{\mathrm{b}}$ & $35.7^{\mathrm{c}}$ & $2.62^{\mathrm{b}}$ & $11.5^{\mathrm{a}}$ & $10.4^{\mathrm{a}}$ & $32.5^{\mathrm{a}}$ & 11.0 & $1.34^{\mathrm{b}}$ \\
\hline Tall fescue & $7.47^{\mathrm{a}}$ & $64.9^{\mathrm{a}}$ & $36.6^{\mathrm{b}}$ & $2.69^{\mathrm{b}}$ & $9.1^{\mathrm{c}}$ & $8.5^{\mathrm{b}}$ & $24.7^{\mathrm{b}}$ & 9.6 & $1.37^{\mathrm{a}}$ \\
\hline $\mathrm{SEM}^{5}$ & 0.272 & 0.36 & 0.27 & 0.075 & 0.13 & 0.21 & 0.85 & 0.50 & 0.004 \\
\hline Cut & 5.35 & 63.7 & 37.2 & 2.76 & 10.1 & 8.8 & 27.6 & 10.4 & 1.35 \\
\hline Uncut & 5.34 & 63.6 & 37.1 & 2.78 & 10.1 & 8.9 & 27.8 & 10.2 & 1.35 \\
\hline $\mathrm{SEM}^{5}$ & 0.223 & 0.29 & 0.22 & 0.061 & 0.11 & 0.17 & 0.69 & 0.41 & 0.004 \\
\hline$P>F^{6}$ & 0.968 & 0.973 & 0.697 & 0.828 & 0.712 & 0.702 & 0.853 & 0.730 & 0.861 \\
\hline \multicolumn{10}{|l|}{ Moisture $^{8}$} \\
\hline High & $4.63^{\mathrm{b}}$ & $62.9^{\mathrm{b}}$ & 37.2 & 2.72 & $10.3^{\mathrm{a}}$ & $9.1^{\mathrm{a}}$ & $23.7^{\mathrm{b}}$ & 10.9 & 1.35 \\
\hline Ideal & $6.07^{\mathrm{a}}$ & $64.4^{\mathrm{a}}$ & 37.1 & 2.82 & $9.9^{\mathrm{b}}$ & $8.7^{\mathrm{b}}$ & $31.7^{\mathrm{a}}$ & 9.7 & 1.35 \\
\hline
\end{tabular}

${ }^{\mathrm{a}-\mathrm{c}}$ Means within a column and main effect without common superscripts differ at $P \leq 0.05$.

${ }^{1} \mathrm{NE}_{\mathrm{L}}$ calculated per NRC (2001) recommendations with the ADL option used to calculate truly digestible fiber.

${ }^{2} \mathrm{WSC}=$ water-soluble carbohydrates.

${ }^{3} \mathrm{NDICP}=$ neutral-detergent insoluble CP.

${ }^{4} \mathrm{ADICP}=$ acid-detergent insoluble $\mathrm{CP}$.

${ }^{5}$ Pooled SE of the main-effect mean.

${ }^{6}$ Test of significance for the main-effect mean.

${ }^{7} \mathrm{Cut}=$ bales made with bale-cutting system engaged; uncut $=$ bales made without particle-length reduction.

${ }^{8}$ High-moisture mean across all baling treatments was $58.3 \%$; for ideal moisture, the mean across all treatments was $44.9 \%$. 
relationships between forage moisture concentration, WSC, and final $\mathrm{pH}$ for alfalfa-grass mixtures ensiled as large round bales; in that experiment, drier bales (49.4 to $53.5 \%$ ) exhibited significantly greater residual WSC and a greater final $\mathrm{pH}$ than wetter bales (59.5 to $65.0 \%)$. Within the present experiment, the calculated cost of fermentation across all bales for energy (preensiled $\mathrm{NE}_{\mathrm{L}}-$ postensiled $\mathrm{NE}_{\mathrm{L}}$ ) was small $(0.03 \mathrm{Mcal} /$ $\mathrm{kg}$ ), or about $2.2 \%$, which is consistent with the overall good recovery of DM (93.6\%) observed collectively within these bales. As observed on a preensiled basis, bale cutter engagement had no effect $(P \geq 0.158)$ on any measure of nutritive value.

\section{In Vitro Digestibility}

asNDFom. In vitro digestibility of asNDFom (NDFD) following a 30 -h incubation was affected $(P$ $<0.001$ ) by forage type on both a pre- and postensiled basis (Figure 4). Regardless of sampling time, NDFD was greatest $(P<0.001)$ for orchardgrass, with meadow fescue greater $(P \leq 0.022)$ than tall fescue. Moreover, the magnitude of differences between orchardgrass and meadow fescue was quite large, amounting to 11.3 and 11.2 percentage units calculated on a pre-and postensiled basis, respectively. Differences in NDFD between meadow and tall fescue were narrower by comparison (4.1 and 3.5 percentage units, respectively). The greater NDFD observed for orchardgrass compared with other forages cannot be conclusively explained on the basis of detergent fiber composition. Although statistical differences were observed between forage types for concentrations of specific fiber components (Tables 2 and 3), the overall range across forages was relatively narrow; for example, ranges were 1.8 and 3.3 percentage units of NDF for pre- and postensiled forages, respectively, and concentrations of ADL did not differ in preensiled forages (overall mean $=2.84 \% ; P=0.119$ ). This suggests the nonflowering growth response by orchardgrass did not have a great effect on fiber composition based on typical detergent analysis, but may have been responsible for this large discrepancy in NDFD between orchardgrass and other forages. Generally, past work suggests that meadow fescue should exhibit lower concentrations of NDF, greater NDFD, and have greater milk production potential than most other perennial cool-season grasses grown in Wisconsin (Brink et al., 2007, 2008, 2010). Although these relationships were corroborated for meadow and tall fescue with respect to NDFD, the high NDFD ( 56.2 and $55.0 \%$ of as NDFom) observed for pre-and postensiled orchardgrass was unexpected. Furthermore, the $\mathrm{NE}_{\mathrm{L}}$ estimates for these forages (Tables 2 and 3) were based on inputs

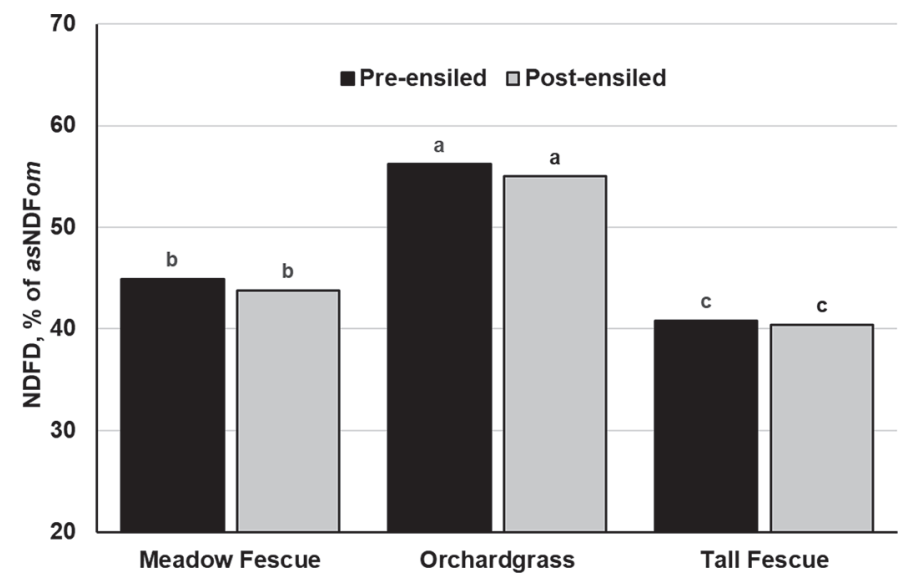

Figure 4. In vitro (30-h) digestion of NDF (NDFD; \% of asNDFom) for preensiled or postensiled perennial grass baled silages made in Stratford, Wisconsin. The NDF analysis included $\alpha$-amylase and sodium sulfite, and the insoluble fiber was corrected for residual ash. The SEM for preensiled forage-type main-effect means was $0.82 \%$ of as NDF om. Similarly, for postensiled forages, the SEM was $0.99 \%$ of asNDFom. Pre- and postensiled forages were analyzed separately; within each of those designations, means without common superscripts differed at $P<0.05$.

of N-corrected NDF and ADL to calculate the truly digestible-fiber component of TDN (NRC, 2001). Acknowledging that rates of fiber digestibility were not evaluated, and might well differ considerably between forages, these data collectively suggest a discrepancy may exist between the ADL and in vitro options for determining truly digestible fiber for these nonflowering (vegetative) orchardgrass forages compared with fully headed meadow and tall fescues.

IVDMD. In vitro digestibility of $\mathrm{DM}$ following a 30-h incubation (IVDMD) also was affected $(P<0.001)$ by forage type and exhibited similar response patterns across forage types as those described for NDFD. For preensiled forages (Figure 5), IVDMD for orchardgrass $(60.0 \%)$ exceeded $(P \leq 0.001)$ that of meadow and tall fescue by 3.6 and 7.6 percentage units, respectively. As observed for NDFD, meadow and tall fescue also differed $(P<0.001)$. On a poststorage basis, responses were similar, except that differences between orchardgrass and meadow or tall fescue were somewhat greater (6.2 and 9.1 percentage units, respectively).

On a poststorage basis, effects of moisture category were also detectable, with HM bales exhibiting greater NDFD (48.3 vs. $44.5 \%$ of asNDFom; $P \leq 0.001$ ) and IVDMD (59.8 vs. $56.9 \%$ of DM; $P \leq 0.001)$ than IM bales. Effects of moisture category were not observed before ensiling for either response variable $(P \geq 0.335)$. Engagement of the bale-cutting system had no effect $(P \geq 0.610)$ on NDFD or IVDMD on either a pre- or postensiled basis. 


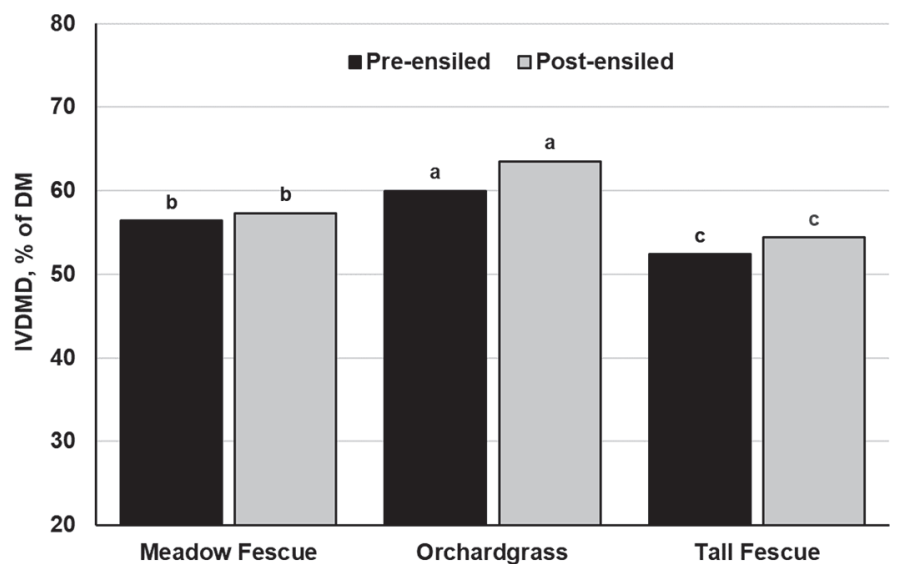

Figure 5. In vitro (30-h) digestion of DM (IVDMD; \% of DM) for preensiled or postensiled perennial grass baled silages made in Stratford, Wisconsin. The SEM for preensiled forage-type main-effect means was $0.60 \%$ of DM. Similarly, for postensiled forages, the SEM was $0.80 \%$ of DM. Pre- and postensiled forages were analyzed separately; within each of those designations, means without common superscripts differed at $P<0.05$.

\section{Silage Fermentation Characteristics}

Concentrations of silage fermentation products were affected primarily by the moisture main effect (Table 4), which was highly significant $(P \leq 0.001)$ for all response variables except for acetic acid (overall mean $=0.78 \%$;
$P=0.500)$. In each case, fermentation products were greater $(P \leq 0.001)$ for HM compared with IM bales. Of particular importance were concentrations of total VFA (4.34 vs. $2.08 \%)$ and lactic acid (2.62 vs. $1.08 \%$ ), which resulted collectively in a more acidic final $\mathrm{pH}$ (5.33 vs. 5.82). Concomitant with increased production of total VFA and lactic acid, HM bales also exhibited greater $(P<0.001)$ concentrations of propionic $(0.44$ vs. $0.13 \%)$ and butyric acids (0.52 vs. $0.06 \%$ ), as well as $\mathrm{NH}_{3}-\mathrm{N}$ (9.16 vs. $5.21 \%$ of $\mathrm{N}$ ) compared with IM bales. These responses are consistent with wet forages and indicate that some clostridial activity occurred in HM bales. Concentrations of propionic and butyric acids exceeded recommended targets $(<0.1 \%)$ for silages suggested by Kung and Shaver (2001) and Mahanna and Chase (2003), although responses for $\mathrm{NH}_{3}-\mathrm{N}$ (\% of $\mathrm{N})$ generally fell within acceptable ranges suggested by those reference sources. Although propionic acid exhibits well-known properties of extending aerobic stability, it is the product of clostridia and propionic-acid bacteria, both of which use lactic acid as a substrate (McDonald et al., 1991). Furthermore, at the final pH reported for silages throughout this study, propionic acid would exist in a largely disassociated form (pKa $=4.87$ ), thereby substantially limiting its effectiveness at extending aerobic stability (Kung et al., 2003). Although highly undesirable as a fermentation product,

Table 4. Main effects of forage type and moisture grouping on selected silage fermentation products for 47 round bales of perennial grasses harvested during 2018 near Stratford, Wisconsin ${ }^{1}$

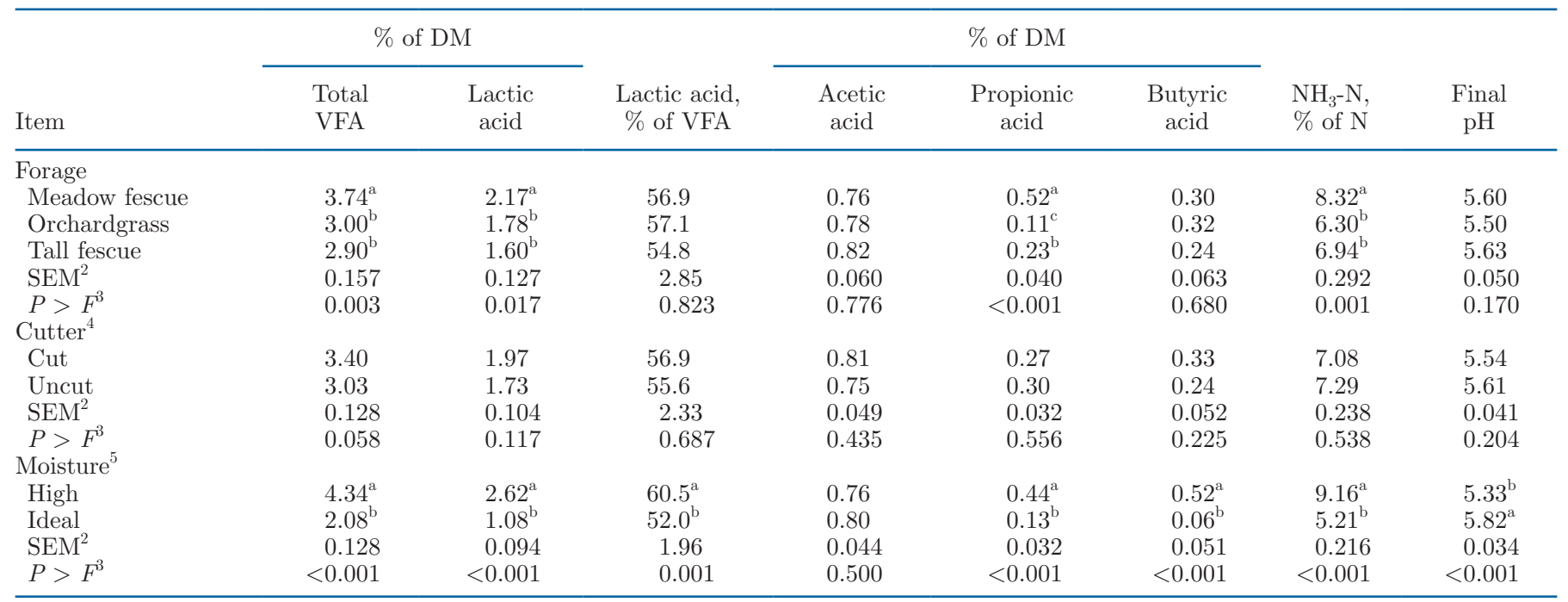

\footnotetext{
${ }^{\mathrm{a}-\mathrm{c}}$ Means within a column and main effect without common superscripts differ at $P \leq 0.05$.

${ }^{1}$ Selected fermentation products exhibited no interactions of main effects $(P \geq 0.145)$.

${ }^{2} \mathrm{SEM}=$ standard error of the pooled main-effect mean.

${ }^{3}$ Test of significance for the main-effect mean.

${ }^{4} \mathrm{Cut}=$ bales made with bale-cutting system engaged; uncut $=$ bales made without particle-length reduction.

${ }^{5}$ High-moisture mean across all baling treatments was $58.3 \%$; for ideal moisture, the mean across all treatments was $44.9 \%$.
} 
butyric acid possesses strong antifungal properties, and also is known impart aerobic stability to silages exposed to air (Kung et al., 2018).

Generally, the effects of forage moisture on silage fermentation are well known and have been discussed frequently (McDonald and Edwards, 1976; Muck, 1988; McDonald et al., 1991; Buxton and O'Kiely, 2003). However, much of this discussion has been oriented toward precision-chopped silages and biased toward limiting the negative consequences of ensiling excessively wet silages, such as preventing DM loss and limiting production of butyric acid or $\mathrm{NH}_{3}-\mathrm{N}$ (or both), as opposed to the positive relationship between production of desirable fermentation products and moisture concentration, particularly when considered within the context of common moisture recommendations (45 to $55 \%$ ) for baled silages Shinners (2003). This concept was illustrated clearly for baled silages in early work (Nicholson et al., 1991) and has been summarized recently (Coblentz and Akins, 2018) with some emphasis on the highly restrictive nature of fermentation in baled silages, particularly when moisture concentrations fall below those recommended by Shinners (2003). Buxton and O'Kiely (2003) summarized that silage fermentation occurs in the liquid state of herbage, and that water aids compaction and subsequent transition to an anaerobic state; however, Muck (1988) also has noted that fermentation and the associated $\mathrm{pH}$ decline are relatively unimportant in producing high-quality dry $(<45 \%)$ silages because clostridia are inhibited under those conditions.

In addition to moisture category, the main effect of forage type affected $(P \leq 0.017)$ concentrations of total VFA, lactic acid, propionic acid, and $\mathrm{NH}_{3}-\mathrm{N}$, with meadow fescue exhibiting the greatest $(P \leq 0.049)$ concentration in each case. It is difficult to assess whether these differences are related to inherent characteristics of each forage, or confounding factors. The BC (Table 1) and preensiled concentration of WSC (Table 2) for meadow fescue were both intermediate between the other forages, but final moisture concentrations differed between meadow fescue and orchardgrass for both HM and IM bales, and there was a particularly large differential for IM bales (51.1 vs. 42.4\%; Figure 4). Furthermore, it is difficult to assess the effects of nonflowering in orchardgrass, which affected DM yield, swath density, drying rate, and DM bale density, all of which could indirectly affect fermentation.

Although bale-cutter engagement did not affect $(P$ $\geq 0.058$ ) any measure of silage fermentation, there was a tendency ( 3.40 vs. $3.03 \% ; P=0.058$ ) for greater production of total VFA in cut bales. These results suggest cutter engagement during production of perennial cool-season grass silages may produce minor increases in bale density, but impart little practical benefit to silage fermentation.

\section{CONCLUSIONS}

Of the experimental factors evaluated, bale moisture had the greatest effect on production of fermentation acids and the final silage $\mathrm{pH}$, resulting in a $0.49-\mathrm{pH}$ unit difference between HM and IM bales. Only limited effects were imparted by forage type or particle-length reduction. Engagement of the bale-cutting mechanism for silage bales made from 3 perennial cool-season grasses increased initial wet and dry bale weights by 4.1 and $4.7 \%$, respectively, which is consistent with past work. These very modest increases in bale weights in response to forage particle-size reduction had no practical effect on measures of nutritive value, either on a pre- or postensiled basis. For cut silages, a tendency for increased concentrations of VFA was observed, but the overall $\mathrm{pH}$ reduction of $0.07 \mathrm{pH}$ units compared with uncut silages was not statistically significant. The unique nonflowering (vegetative) growth response by the orchardgrass forages in this study produced marked increases in 30-h NDFD and IVDMD relative to meadow or tall fescue, which could not be clearly explained on the basis of detergent-based fiber composition. Meadow fescue corroborated a commonly reported digestibility advantage over tall fescue with respect to NDFD, but was not comparable to orchardgrass exhibiting a nonflowering growth response. The addition of cutting mechanisms within balers to reduce forage particle length may have specific advantages over uncut silages, such as improving ease of mixing in blended diets, but there is little obvious benefit with respect to improved silage fermentation or ensuring against clostridial activity in wet silages.

\section{ACKNOWLEDGMENTS}

Mention of trade names or commercial products in this article is solely for the purpose of providing specific information, and does not imply either recommendation or endorsement by the U.S. Department of Agriculture. The USDA is an equal opportunity provider and employer. The authors have not stated any conflicts of interest.

\section{REFERENCES}

Ankom Technology. 2017. In vitro true digestibility using the DAISYII incubator. ANKOM Technology Corp., Macedon, NY. Accessed Feb. 3, 2019. https://www.ankom.com/sites/default/files/ document-files/Method_3_Invitro_D200_D200I.pdf. 
AOAC International. 1998. Official Methods of Analysis, AOAC Official Method \#990.03. 16th ed., 4th rev. Association of Official Analytical Chemists, Gaithersburg, MD.

Berg, C. C., G. M. Wood, A. W. Hovin, and C. M. Rincker. 1981. Floral induction and forage yield and quality of sparse-flowering orchardgrass synthetics. Crop Sci. 21:677-680. https://doi.org/10 $.2135 /$ cropsci1981.0011183X002100050011x.

Borreani, G., and E. Tabacco. 2006. The effect of a baler chopping system on fermentation and losses of wrapped big bales of alfalfa. Agron. J. 98:1-7. https://doi.org/10.2134/agronj2004.0134.

Brink, G. E., and M. D. Casler. 2009. Meadow fescue, tall fescue, and orchardgrass response to nitrogen application rate. Forage Grazinglands 7:0. https://doi.org/10.1094/FG-2009-0130-01-RS.

Brink, G. E., M. D. Casler, and M. B. Hall. 2007. Canopy structure and neutral detergent fiber differences among temperate perennial grasses. Crop Sci. 47:2182-2189. https://doi.org/10.2135/ cropsci2007.01.0045.

Brink, G. E., M. D. Casler, and N. P. Martin. 2010. Meadow fescue, tall fescue, and orchardgrass response to defoliation management. Agron. J. 102:667-674. https://doi.org/10.2134/agronj2009.0376.

Brink, G. E., M. F. Digman, and R. E. Muck. 2014. Field-drying rate differences among three cool-season grasses. Forage Grazinglands 12:0. https://doi.org/10.2134/FG-2013-0104-RS.

Brink, G. E., M. B. Hall, D. R. Mertens, and M. D. Casler. 2008. Grass yield and quality affect potential stocking rate and milk production. Forage Grazinglands https://doi.org/10.1094/FG-2008-0312 $-01-\mathrm{RS}$.

Buxton, D. R., and P. O'Kiely. 2003. Preharvest plant factors affecting ensiling. Pages 199-250 in Silage Science and Technology. D. R. Buxton, R. E. Muck, and J. H. Harrison, ed. American Society of Agronomy, Crop Science Society of America, and Soil Science Society of America, Madison, WI.

Casler, M. D., R. E. Barker, J. H. Cherney, and Y. A. Papadopolous. 2004. Stability of nonflowering orchardgrass. Crop Sci. 44:16011607. https://doi.org/10.2135/cropsci2004.1601.

Casler, M. D., D. J. Undersander, Y. A. Papadopolous, S. Bittman, D. Hunt, R. D. Mathison, D. H. Min, J. G. Robins, J. H. Cherney, S. N. Acharya, D. P. Belesky, S. R. Bowley, B. E. Coulman, R. Drapeau, N. J. Ehlke, M. H. Hall, R. H. Leep, R. Michaud, J. Rowsell, G. E. Shewmaker, C. D. Teutsch, and W. K. Coblentz. 2014. Sparse-flowering orchardgrass represents an improvement in forage quality during reproductive growth. Crop Sci. 54:421-429. https://doi.org/10.2135/cropsci2013.04.0227.

Coblentz, W. K., and M. S. Akins. 2018. Recent advances and future technologies for baled silages. J. Dairy Sci. 101:4075-4092. https:/ /doi.org/10.3168/jds.2017-13708.

Coblentz, W. K., and M. S. Akins. 2019. Nutritive value and fermentation characteristics of round-baled alfalfa-orchardgrass forages ensiled at various moisture concentrations with or without baler cutting engagement. Appl. Anim. Sci. 35:135-145. https://doi.org/10 .15232/aas.2018-01837.

Coblentz, W. K., M. S. Akins, K. F. Kalscheur, G. E. Brink, and J. S. Cavadini. 2018. Effects of growth stage and growing degree day accumulations on triticale forages: 1) Dry matter yield, nutritive value, and in vitro dry matter disappearance. J. Dairy Sci. 101:8965-8985. https://doi.org/10.3168/jds.2018-14868.

Coblentz, W. K., K. P. Coffey, and E. A. Chow. 2016a. Storage characteristics, nutritive value, and fermentation characteristics of alfalfa packaged in large-round bales and wrapped in stretch film after extended time delays. J. Dairy Sci. 99:3497-3511. https://doi.org/ $10.3168 / j d s .2015-10380$.

Coblentz, W. K., and R. E. Muck. 2012. Effects of natural and simulated rainfall on indicators of ensilability and nutritive value for wilting alfalfa forages sampled before preservation as silage. J. Dairy Sci. 95:6635-6653. https://doi.org/10.3168/jds.2012-5672.

Coblentz, W. K., R. E. Muck, M. A. Borchardt, S. K. Spencer, W. E. Jokela, M. G. Bertram, and K. P. Coffey. 2014. Effects of dairy slurry on silage fermentation characteristics and nutritive value of alfalfa. J. Dairy Sci. 97:7197-7211. https://doi.org/10.3168/jds $.2014-8582$.
Coblentz, W. K., R. K. Ogden, M. S. Akins, and E. A. Chow. 2016b. Storage characteristics, nutritive value, and fermentation characteristics of large-round bales of alfalfa-mixed grass forage wrapped with different layers of stretch film. Prof. Anim. Sci. 32:805-815. https://doi.org/10.15232/pas.2016-01538.

DuBois, M., K. A. Gilles, J. K. Hamilton, P. A. Rebers, and F. Smith. 1956. Colorimetric method for determination of sugars and related substances. Anal. Chem. 28:350-356. https://doi.org/10.1021/ ac60111a017.

Heide, O. M. 1987. Photoperiodic control of flowering in Dactylis glomerata, a true short-long-day plant. Physiol. Plant. 70:523-529. https://doi.org/10.1111/j.1399-3054.1987.tb02853.x.

Hoffman, P. C., S. J. Sievert, R. D. Shaver, D. A. Welch, and D. K. Combs. 1993. In situ dry matter, protein, and fiber degradation of perennial forages. J. Dairy Sci. 76:2632-2643. https://doi.org/10 .3168/jds.S0022-0302(93)77599-2.

Holland, C., and W. Kezar. 1990. Pioneer Forage Manual-A Nutritional Guide. Pioneer Hi-Bred International, Des Moines, IA.

Hovin, A. W., C. M. Rincker, and G. M. Wood. 1966. Breeding of nonflowering orchardgrass, Dactylis glomerata L. Crop Sci. 6:239-241. https://doi.org/10.2135/cropsci1966.0011183X000600030006x.

Jennings, J. A. 2011. Baled silage for livestock. \#FSA3051-PD4-11RV. University of Arkansas Cooperative Extension Service, Little Rock.

Keles, G., P. O'Kiely, J. J. Lenehan, and P. D. Forristal. 2009. Conservation characteristics of baled grass silages differing in duration of wilting, bale density, and number of layers of plastic stretch-film. Ir. J. Agric. Food Res. 48:21-34.

Kung, L., and R. Shaver. 2001. Interpretation and use of silage fermentation analysis reports. Focus on Forage. Vol. 3. No. 13. University of Wisconsin Extension and College of Agricultural and Life Sciences. Madison, WI.

Kung, L. Jr., R. D. Shaver, R. J. Grant, and R. J. Schmidt. 2018. Silage review: Interpretation of chemical, microbial, and organoleptic components of silages. J. Dairy Sci. 101:4020-4033. https:// doi.org/10.3168/jds.2017-13909.

Kung, L., M. R. Stokes, and C. J. Lin. 2003. Silage additives. Pages 305-360 in Silage Science and Technology. D. R. Buxton, R. E. Muck, and J. H. Harrison, ed. American Society of Agronomy, Crop Science Society of America, and Soil Science Society of America, Madison, WI.

Leibensperger, R. Y., and R. E. Pitt. 1987. A model of clostridial dominance in ensilage. Grass Forage Sci. 42:297-317. https://doi .org/10.1111/j.1365-2494.1987.tb02118.x.

Mahanna, B., and L. E. Chase. 2003. Practical applications and solutions to silage problems. Pages $855-895$ in Silage Science and Technology. D. R. Buxton, R. E. Muck, and J. H. Harrison, ed. American Society of Agronomy, Crop Science Society of America, and Soil Science Society of America, Madison, WI.

McDonald, P., and R. A. Edwards. 1976. The influence of conservation methods on digestion and utilization of forages by ruminants. Proc. Nutr. Soc. 35:201-211. https://doi.org/10.1079/PNS19760033.

McDonald, P., A. R. Henderson, and S. J. E. Heron. 1991. The Biochemistry of Silage. 2nd ed. Chalcombe Publications, Marlow, Buckinghamshire, UK.

Muck, R. E. 1988. Factors influencing silage quality and their implications for management. J. Dairy Sci. 71:2992-3002. https://doi .org/10.3168/jds.S0022-0302(88)79897-5.

Muck, R. E., L. E. Moser, and R. E. Pitt. 2003. Postharvest factors affecting ensiling. Pages 251-304 in Silage Science and Technology. D. R. Buxton, R. E. Muck, and J. H. Harrison, ed. American Society of Agronomy, Crop Science Society of America, and Soil Science Society of America, Madison, WI.

Muck, R. E., P. O'Kiely, and R. K. Wilson. 1991. Buffering capacities in permanent pasture grasses. Isr. J. Agric. Res. 30:129-141.

Muck, R. E., and R. P. Walgenbach. 1985. Variations in alfalfa buffering capacity. ASAE Paper No. 85-1535. Am. Soc. Agric. Eng., St. Joseph, MI.

Nicholson, J. W. G., R. E. McQueen, E. Charmley, and R. S. Bush. 1991. Forage conservation in round bales or silage: effect on ensil- 
ing characteristics and animal performance. Can. J. Anim. Sci. 71:1167-1180. https://doi.org/10.4141/cjas91-138.

NRC. 2001. Nutrient Requirements of Dairy Cattle. 7th rev. ed. National Academy Press, Washington, DC.

Savoie, P., and J. C. Jofriet. 2003. Silage storage. Pages 405-468 in Silage Science and Technology. D. R. Buxton, R. E. Muck, and J. H. Harrison, ed. American Society of Agronomy, Crop Science Society of America, and Soil Science Society of America, Madison, WI.

Scarbrough, D. A., W. K. Coblentz, J. B. Humphry, K. P. Coffey, T. C. Daniel, T. J. Sauer, J. A. Jennings, J. E. Turner, and D. W. Kellogg. 2005. Evaluation of dry matter loss, nutritive value, and in situ dry matter disappearance for wilting orchardgrass and bermudagrass forages damaged by simulated rainfall. Agron. J. 97:604-614. https://doi.org/10.2134/agronj2005.0604.

Schaefer, M. R., K. A. Albrecht, and D. M. Schaefer. 2014. Stocker steer performance on tall fescue or meadow fescue alone or in a binary mixture with white clover. Agron. J. 106:1902-1910. https: //doi.org/10.2134/agronj14.0075.

Shinners, K. J. 2003. Engineering principles of silage harvesting management. Pages 361-404 in Silage Science and Technology. D. R.
Buxton, R. E. Muck, and J. H. Harrison, ed. American Society of Agronomy, Crop Science Society of America, and Soil Science Society of America, Madison, WI.

Shinners, K. J., B. M. Huenink, R. E. Muck, and K. A. Albrecht. 2009. Storage characteristics of large round and square alfalfa bales: Low-moisture wrapped bales. Trans. ASABE 52:401-407. https:// doi.org/10.13031/2013.26824.

Van Soest, P. J., J. B. Robertson, and B. A. Lewis. 1991. Methods for dietary fiber, neutral detergent fiber, and nonstarch polysaccharides in relation to animal nutrition. J. Dairy Sci. 74:3583-3597. https://doi.org/10.3168/jds.S0022-0302(91)78551-2.

\section{ORCIDS}

W. K. Coblentz ๑ https://orcid.org/0000-0003-2477-3449

M. S. Akins @ (ttps://orcid.org/0000-0001-5517-1681 